\title{
Aqueous extract of Kan-Lu-Hsiao-Tu-Tan ameliorates collagen-induced arthritis in mice by regulating immune and inflammatory responses
}

Chih-Chao Chiang

Chang Gung University

\section{Yi-Rong Li}

Changhua Christian Hospital

Kuei-Hung Lai

Chang Gung University of Science and Technology

Wei-Jen Cheng

Chang Gung University

Shih-Chao Lin

George Mason University

Yi-Hsuan Wang

Chang Gung University

Po-Jen Chen

Providence University

Sien-Hung Yang

Chang Gung University

Tsong-Long Hwang ( $\sim$ ht|@mail.cgu.edu.tw)

Chang Gung University https://orcid.org/0000-0002-5780-3977

Chi-Chien Lin

National Chung-Hsing University

\section{Research Article}

Keywords: Kan-Lu-Hsiao-Tu-Tan, collagen-induced arthritis, inflammation, immunity, Chinese medicine

Posted Date: October 29th, 2020

DOl: https://doi.org/10.21203/rs.3.rs-45310/v2

License: (c) (1) This work is licensed under a Creative Commons Attribution 4.0 International License.

Read Full License 


\section{Abstract}

Abstract: Background: Kan-Lu-Hsiao-Tu-Tan (KLHTT) exhibits anti-psoriatic effects through antiinflammatory activity in mice. However, the therapeutic effects of KLHTT on rheumatoid arthritis (RA), another significant autoimmune inflammatory disorder, are not elucidated. Herein, we explored the antiarthritic effects of KLHTT on collagen-induced arthritis (CIA) in mice. Methods: KLHTT was extracted by boiling water and subjected to spectroscopic analysis. Chicken collagen type II (CII) with complete Freund's adjuvant was intradermally injected to induce CIA in DBA/1J mice. Anti-Cll antibody, cytokines, malondialdehyde (MDA), and hydrogen peroxide $\left(\mathrm{H}_{2} \mathrm{O}_{2}\right)$ were measured using ELISA, thiobarbituric acid reactive substances, and hydrogen peroxide assay kit. Splenocyte proliferation was tested using thymidine incorporation. Th1 and Th17 cells were analyzed by flow cytometry. Results: Oral KLHTT treatment ( 50 and $100 \mathrm{mg} / \mathrm{kg}$ ) ameliorated mouse CIA by decreasing the levels of interleukin (IL)-1ß, IL-6, IL-17A, and tumour necrosis factor- $a$ in the paw homogenates and serum. KLHTT also suppressed antiCll antibody formation, splenocyte proliferation, and splenic Th1 and Th17 cell numbers. Additionally, KLHTT showed antioxidant activity by reducing the concentrations of MDA and $\mathrm{H}_{2} \mathrm{O}_{2}$ in paw tissues. Conclusions: The therapeutic effects of KLHTT in CIA mice were through regulating oxidative stress and inflammatory responses. Our results suggest that KLHTT has potential to treat RA.

\section{Introduction}

Rheumatoid arthritis (RA) is an autoimmune disease affecting approximately $1 \%$ of the global population, which is characterised by synovitis, cartilage damage, and bone resorption in the joint [1]. Moreover, RA is associated with fatigue [2], cervical spine disease, carpal tunnel syndrome [3], interstitial lung disease [4], cardiovascular disease [5], depression [6], and sleep disorders [7]. RA can cause personal and emotional problems, and impose a significant socio-economic burden $[8,9]$. The medical treatment of RA includes biological disease-modifying anti-rheumatic drugs, conventional disease-modifying antirheumatic drugs, and analgesics. However, these available therapies cannot treat the disease completely and exert significant side effects. Therefore, the development of new therapeutics for RA is needed $[10,11]$.

RA is characterised by synovitis accompanied by the infiltration of immune cells [12], including $T$ cells, $B$ cells, dendritic cells [13], neutrophils [14], and macrophages [15]. Studies have indicated that anticitrullinated protein antibodies (ACPAs) and inflammatory cytokines, such as interleukin (IL)-1ß, IL-6, IL17, and tumour necrosis factor-alpha (TNF- $a$ ), are pivotal mediators in RA [16]. ACPA is also a specific diagnostic biomarker for RA [17]. Furthermore, oxidative stress caused by reactive oxygen species (ROS) is crucial in joint inflammation, and RA patients exhibit high level of ROS in serum [18,19]. Hence, antioxidant drugs may be effective in treating RA [20]. Collagen-induced arthritis (CIA) in mice recapitulates the clinical and pathogenic characteristics of human RA, and are widely used to study RA [21]. 
Kan-Lu-Hsiao-Tu-Tan (KLHTT), a Chinese medicine (CM), has been used to treat inflammatory conditions such as RA, systemic lupus erythematosus, dermatomyositis [22], sinusitis, gingivitis, gastritis, hepatitis [23], and dermatitis [24]. Our previous study demonstrated that KLHTT exerts ROS scavenging ability and anti-inflammatory activity in human neutrophils and exhibits anti-psoriatic activity in mice [25]. However, the pharmacologic effects of KLHTT on RA, another significant autoimmune inflammatory disorder, are not yet elucidated. Herein, in this study, we aimed to investigate the anti-arthritic effects of KLHTT in CIA mice and evaluate its value in the treatment of RA.

\section{Materials And Methods}

\subsection{Reagents}

KLHTT (batch number: 0503-2-403-01) was supplied by Sun Ten Pharmaceutical Corporation, New Taipei City, Taiwan. Chicken collagen type II (CII) was purchased from Chondrex, Inc., WA, USA. Mycobacterium tuberculosis H37RA was bought from Difco Laboratories Inc., MI, USA. Methotrexate (MTX) and EDTA were ordered from Bio Basic Inc., Toronto, Canada. Enzyme-linked immunosorbent assay (ELISA) kits (for IL-1 $\beta$, IL-6, and TNF-a) were obtained from eBioscience, San Diego, CA, USA. An IL17A ELISA kit was purchased from R\&D Systems Inc., Minneapolis, MN, USA. A hydrogen peroxide assay kit was purchased from Cell Biolabs, Inc, San Diego, CA, USA. Goat anti-mouse IgG1 and goat anti-mouse IgG2a secondary antibodies were purchased from Jackson ImmunoResearch Laboratories, PA, USA.

ABTS substrate solution was ordered form Roche Diagnostic Systems, CA, USA. A ${ }^{3} \mathrm{H}$ labelled compound was purchased from Amersham Pharmacia Biotech, Arlington Heights, IL, USA. Brefeldin A and Freund's adjuvant were bought from Sigma-Aldrich, St. Louis, MO, USA. PE-conjugated anti-mouse CD4 (clone GK1.5), FITC-conjugated anti-mouse IL-17A (clone TC11-18H10.1), and FITC-conjugated anti-mouse interferon (IFN) $-\mathrm{y}$ (clone XMG1.2) antibodies were ordered from Biolegend, San Diego, CA, USA. Formalin was bought from AVANTOR, Center Valley, PA. Bovine serum albumin (BSA) was purchased from EMD Millipore, Billerica, MA, USA. Tween 20 was obtained from EMD Millipore, France.

\subsection{KLHTT preparation}

The herbs of KLHTT were purchased and identified by Sun Ten Pharmaceutical Corporation, New Taipei City, Taiwan. A total of $27.93 \mathrm{~g}$ of herbs (6.25 g Soapstone, $4.58 \mathrm{~g}$ Artemisia capillaris Thunb. (seedling), $4.17 \mathrm{~g}$ Scutellaria baicalensis Georgi (root), $2.50 \mathrm{~g}$ Acorus gramineus Soland. (rhizome), $2.08 \mathrm{~g}$ Clematis armandii Franch. (rattan and stem), $2.08 \mathrm{~g}$ Fritillaria cirrhosa D. Don (bulb), $1.67 \mathrm{~g}$ Pogostemon cablin (Blanco) Benth. (plant shoot), $1.67 \mathrm{~g}$ Forsythia suspensa (Thunb.) Vahl (fruits), $1.67 \mathrm{~g} \mathrm{Amomum}$ kravanh Pierre ex Gagnep. (fruits), $1.67 \mathrm{~g}$ Mentha haplocalyx Briq. (stem and leaf plot), and $1.67 \mathrm{~g}$ Belamcanda chinensis (L.) DC (rhizome)) was extracted by boiling water (12 times the weight of the herbs) for $1 \mathrm{~h}$, and then concentrated to a voucher specimen (CGU_KLHTT-01) by the freeze dryer (LABCONCO, USA) [25]. The voucher specimen complied with Chang Gung University guidelines. 


\subsection{Ultra-performance liquid chromatography-tandem mass spectrometry}

The chemical profile of KLHTT extract was obtained using ultra-performance liquid chromatographytandem mass spectrometry (UPLC-MS/MS) comprising a LC-30AD pump, SIL-30AC auto-sampler, CTO20AC column, and SPD-M20A Photodiode Array Detector (Nexera X2, Shimazu, Kyoto, Japan). Prior to being loaded onto the UPLC column, $1 \mathrm{mg}$ of KLHTT extract was first dissolved in $1 \mathrm{~mL}$ of methanol and filtered through a $0.45 \mu \mathrm{m}$ membrane. Sample injections of $1 \mu \mathrm{L}$ were then performed automatically. Liquid chromatography was performed using a CORTECS UPLC C18 column $(90 \AA$, $1.6 \mu \mathrm{m}, 2.1 \mathrm{~mm} \times 100$ $\mathrm{mm}$ ) (Waters, MA, USA). The mobile phase was a mixture of $\operatorname{MeCN}(\mathrm{A})$ and water (W, containing $0.1 \%$ formic acid). A gradient sequence was executed as follows: 0-10 min, 10-20 \% A; 10-14 min, 20-25\% A; 14-24 min, 25-30\% A; 24-28 min, 30-40\% A; 28-33 min, 40-50\% A; 33-38 min, 50-75\% A; 38-40 $\min , 75-100 \% \mathrm{~A}$; and $40-43 \mathrm{~min}, 100 \% \mathrm{~A}$. The column temperature was set at $35^{\circ} \mathrm{C}$. The flow rate was at $0.4 \mathrm{~mL} / \mathrm{min}$. The range of detection wavelengths was fixed in the $190-500 \mathrm{~nm}$.

Multiple reaction monitoring (MRM) experiments (in negative) were carried out using Shimazu LCMS8045 triple quadrupole mass spectrometry to identify the constituents of KLHTT extract. The precursor ion settings of the corresponding profiling peaks were determined using the full scan experiment (50$1000 \mathrm{amu}$ ). The product ions were settled according to previously reported data. The dwell time was fixed at $100 \mathrm{~ms}$ and the collision energy was set at $25-45 \mathrm{eV}$. All MS data were acquired and processed using LCMS LabSolutions software Version 5.93 (Shimazu, Kyoto, Japan).

\subsection{Experimental animals}

DBA/1J mice (male, six- to eight-week old, weight 20-22 g) were purchased from Jackson Laboratories (Bar Harbor, ME, USA) and maintained at $20-25^{\circ} \mathrm{C}$ with half day light/dark cycle under a specific pathogen-free condition. All mice were treated according to the guidelines of the Institutional Animal Care and Use Committee of National Chung Hsing University ( $\mathrm{NCHU}$ ). The study protocol was approved by $\mathrm{NCHU}$ ethics committee.

\subsection{CIA model establishment}

CIA was induced by active immunisation with chicken CII [26]. Briefly, $2 \mathrm{mg} / \mathrm{ml} \mathrm{Cll} \mathrm{was} \mathrm{dissolved} \mathrm{in} 10$ $\mathrm{mM}$ acetic acid solution and emulsified with an equal volume of complete Freund's adjuvant containing Mycobacterium tuberculosis H37RA ( $250 \mu \mathrm{g} /$ mouse). The mixture ( $200 \mu \mathrm{L} /$ mouse) was intradermally injected at the base of the tail. Incomplete Freund's adjuvant and Cll were administered as booster injections to the mice 21 days after the first immunisation. $\mathrm{ddH}_{2} \mathrm{O}, \mathrm{KLHTT}$, or MTX was administered orally once a day from day 21 to 42 . Mice were divided into four groups ( $n=6 /$ group) randomly as 
follows: Group I, Normal; Group II, Vehicle $\left(\mathrm{ddH}_{2} \mathrm{O}\right)$ + Cll; Group III, KLHTT (50 mg/kg) + CIl; Group IV, $\mathrm{KLHTT}(100 \mathrm{mg} / \mathrm{kg})+\mathrm{Cll}$. MTX $(0.5 \mathrm{mg} / \mathrm{kg})$ was used as positive control. Mice were euthanized with $\mathrm{CO}_{2}$ exposure $\left(100 \% \mathrm{CO}_{2}\right.$ for $\left.5 \mathrm{~min}\right)$ by experienced experimenters humanely on day 42 .

\subsection{Assessment of clinical arthritis severity}

The body weight and arthritis severity score were obtained [26]. The arthritis severity score was evaluated as: 0 , no swelling nor redness; 1 , mild swelling and redness restricted to the tarsals or the ankle joint; 2 , mild swelling and redness from the tarsals to the ankle; 3 , moderate swelling and redness extending to the metatarsal joints; 4 . severe swelling and redness from the ankle to the foot and the digits, or limb ankyloses. In addition, paw volume was measured using Plethysmometer 37140 (Ugo Basile SRL, Comerio, VA, Italy).

\subsection{Assessment of histological arthritis severity}

After the mice were humanly sacrificed, the hind limbs were fixed in $10 \%$ buffered formalin, decalcified in $15 \%$ EDTA, and embedded in paraffin. Serial paraffin sections $(5 \mu \mathrm{m})$ were stained with haematoxylin and eosin. The severity of histopathological lesions was scored [26] as follows: 0 , normal appearance; 1 , mild infiltration of inflammatory cells, mild pannus front, and minimal cartilage damage; 2 , moderate infiltration of inflammatory cells, erosive pannus front, and moderate cartilage damage; 3 : diffuse infiltration of inflammatory cells, severe cartilage damage and bone resorption.

\subsection{Measurement of pro-inflammatory cytokine levels}

Hind paw was dissected and homogenised in ice-cold saline using a tissue homogeniser. After being centrifuged at $3000 \mathrm{rpm}\left(4^{\circ} \mathrm{C}, 10 \mathrm{~min}\right.$, twice), the hind paw homogenates were harvested. Blood was collected from the heart. The levels of cytokines in hind paw homogenates and serum were measured by ELISA [16].

\subsection{Measurement of the concentrations of oxidative markers}

Malondialdehyde (MDA) concentration was determined by thiobarbituric acid reactive substances assay at $532 \mathrm{~nm}$. The standard curve was obtained using 1,1,3,3-tetramethoxypropane. Hydrogen peroxide $\left(\mathrm{H}_{2} \mathrm{O}_{2}\right)$ concentration was measured using a colorimetric OxiSelect ${ }^{\mathrm{TM}}$ hydrogen peroxide assay kit at $560 \mathrm{~nm}[16]$. 


\subsection{Anti-collagen type II antibody analysis}

Serum samples were diluted 1:250 for IgG1 or 1:125 for IgG2a in Tris-buffered saline (1 \% BSA and 0.5 $\%$ Tween 20, pH 8.0), and then transferred to Cll $\left(10 \mu \mathrm{g} / \mathrm{ml}\right.$ ) pre-coated $96-$ well plates (Microtiter ${ }^{\mathrm{TM}}$, Thermo Fisher Scientific, Roskilde, Denmark) at $4{ }^{\circ} \mathrm{C}$ overnight. The plates were washed and incubated with goat anti-mouse secondary antibodies $\lg \mathrm{G} 1$ (1:500 dilution) or IgG2a (1:500 dilution) at $25-27^{\circ} \mathrm{C}$ for $1 \mathrm{~h}$. After being washed, ABTS substrate was added and the reactions were stopped by adding $\mathrm{H}_{2} \mathrm{SO}_{4}$. The level of IgG1 and IgG2a was measured at $450 \mathrm{~nm}$ by an ELISA reader (Sunrise, Tecan Inc., Switzerland) [16].

\subsection{Splenocyte proliferation assay}

Splenocytes ( $4 \times 10^{5}$ cells/well) were cultured with chicken CII $(50 \mu \mathrm{g} / \mathrm{mL})$ at $37^{\circ} \mathrm{C}$ for $40 \mathrm{~h}$, and then incubated with ${ }^{3} \mathrm{H}$ for $8 \mathrm{~h}$. Cell proliferation was evaluated by radioactive thymidine incorporation [16].

\subsection{Intracellular staining}

Splenocytes $\left(1 \times 10^{6}\right.$ cells/well) were cultured with chicken $\mathrm{Cll}(50 \mu \mathrm{g} / \mathrm{mL})$ at $37^{\circ} \mathrm{C}$ for $48 \mathrm{~h}$, and then brefeldin $A(5 \mu \mathrm{g} / \mathrm{mL})$ was added for $6 \mathrm{~h}$. Cells were harvested and extracellularly stained with PEconjugated anti-mouse CD4 antibodies. After being fixed and permeabilised with Cytofix/Cytoperm solution (BD Pharmingen), cells were then intracellularly labelled with FITC-conjugated anti-mouse IL-17A and anti-mouse IFN-y antibodies. Splenocytes were detected by an Accuri $\mathrm{C} 5$ flow cytometer (Accuri Cytometers, Ann Arbor, MI, USA) and analysed by BD Accuri ${ }^{\text {TM }}$ C6 Plus software [26].

\subsection{Statistical analysis}

Data are presented as mean \pm SD. Statistical analyses were performed using one- or two-way ANOVA followed by Tukey's honestly significant difference test. A $P$-value $<0.05$ was considered statistically significant.

\section{Results}

\subsection{Identification of flavone derivatives in KLHTT extract}


In this study, qualitative analysis of flavonoid-derived constituents was performed by UPLC-MS/MS under $330 \mathrm{~nm}$. The most significant components of KLHTT extract were flavonoid derivatives (Fig. 1A). It has been reported that flavone glycosides are the major constituents of KLHTT aqueous extract [27]. To identify the constituents of KLHTT, MRM experiments were conducted. The specific mass fragmentations were compared with previous references [28-34], and eight flavonoids were identified: chrysin 6-Carabinoside-8- $C$-glucoside (1), chrysin 6- $C$-glucoside-8- $C$-arabinoside (2), baicalin (3), norwogonin-7- $O-\beta_{-D^{-}}$ glucuronide (4), chrysin 7-O- $\beta_{-D}$-glucuronide (5), oroxylin A 7-O- $\beta_{-D}$-glucuronide (6), wogonoside (7), and baicalein (8) (Fig. 1B) (Table 1).

Figure 1. The chemical fingerprint of KLHTT. (A) Ultra-performance liquid chromatography with photodiode array detector chromatogram $(\lambda=330 \mathrm{~nm}$ ) of KLHTT extract. (B) The flavonoid derivatives in KLHTT extract were identified by comparing specific liquid chromatography-tandem mass spectrometry monitoring fragmentations with previously reported data, and were determined to be: chrysin 6-Carabinoside-8- $C$-glucoside (1), chrysin 6- $C$-glucoside-8- $C$-arabinoside (2), baicalin (3), norwogonin-7- $O-\beta_{D^{-}}$ glucuronide (4), chrysin 7- $O-\beta_{-D}$-glucuronide (5), oroxylin A 7-O- $\beta_{-D}$-glucuronide (6), wogonoside (7), and baicalein (8). KLHTT, Kan-Lu-Hsiao-Tu-Tan.

Table 1. UV and multi-stage mass spectrometry data for the identification of the constituents of Kan-LuHsiao-Tu-Tan extract. 


\begin{tabular}{|c|c|c|c|c|c|}
\hline No. & $\begin{array}{l}t_{\mathrm{R}} \\
(\mathrm{min})\end{array}$ & Formula & $\begin{array}{l}(-)-E S I-M S / M S \text { Fragment } \\
\text { lons }\end{array}$ & $\begin{array}{l}\lambda_{\max } \\
(\mathrm{nm})\end{array}$ & Identification \\
\hline 1 & 7.269 & $\mathrm{C}_{26} \mathrm{H}_{28} \mathrm{O}_{13}$ & $\begin{array}{l}547,487,457,427,367 \\
337\end{array}$ & $\begin{array}{l}271 \\
317\end{array}$ & $\begin{array}{l}\text { Chrysin } 6-C \text {-arabinoside-8- } C \text { - } \\
\text { glucoside }\end{array}$ \\
\hline 2 & 8.249 & $\mathrm{C}_{26} \mathrm{H}_{28} \mathrm{O}_{13}$ & $547,457,427,367,337$ & $\begin{array}{l}271 \\
317\end{array}$ & $\begin{array}{l}\text { Chrysin } 6-C \text {-glucoside-8-C- } \\
\text { arabinoside }\end{array}$ \\
\hline 3 & 12.674 & $\mathrm{C}_{21} \mathrm{H}_{18} \mathrm{O}_{11}$ & $\begin{array}{l}445,269,251,223,197 \\
113\end{array}$ & $\begin{array}{l}276 \\
316\end{array}$ & Baicalin \\
\hline 4 & 14.321 & $\mathrm{C}_{21} \mathrm{H}_{18} \mathrm{O}_{11}$ & $445,269,241,225,171$ & $\begin{array}{l}278 \\
347\end{array}$ & $\begin{array}{l}\text { Norwogonin-7- } O-\beta_{-D^{-}}^{-} \\
\text {glucuronide }\end{array}$ \\
\hline 5 & 15.209 & $\mathrm{C}_{21} \mathrm{H}_{18} \mathrm{O}_{10}$ & $429,253,209,143,113$ & 267 & Chrysin $7-O-\beta_{-D}-$ glucuronide \\
\hline 6 & 15.455 & $\mathrm{C}_{22} \mathrm{H}_{20} \mathrm{O}_{11}$ & $459,283,268$ & $\begin{array}{l}271 \\
311\end{array}$ & Oroxylin A 7- $0-\beta_{D^{-}}$-glucuronide \\
\hline 7 & 16.345 & $\mathrm{C}_{22} \mathrm{H}_{20} \mathrm{O}_{11}$ & $459,283,268$ & $\begin{array}{l}273 \\
340\end{array}$ & Wogonoside \\
\hline 8 & 19.220 & $\mathrm{C}_{15} \mathrm{H}_{10} \mathrm{O}_{5}$ & $\begin{array}{l}269,251,241,223,195 \\
169,136\end{array}$ & $\begin{array}{l}275 \\
324\end{array}$ & Baicalein \\
\hline
\end{tabular}

\subsection{KLHTT exerts anti-arthritic effects in CIA mice}

The CIA mouse model is a well-established and commonly used model mimicking the clinical symptoms and immunopathogenesis of human RA [35]. Mice immunised with Cll induced increases in clinical arthritis scores, paw volume, and histopathological damage. The normal group exhibited no gross or histological changes. KLHTT (50 and $100 \mathrm{mg} / \mathrm{kg}$ ) showed inhibitory effects on arthritis severity (Fig.

$2 \mathrm{~A}$ ) and paw erythema and swelling (Fig. 2B and 2C). The body weight loss in CIA mice was also restored by KLHTT (Fig. 2D).

Figure 2. KLHTT ameliorates CIA severity. CIA was induced by active immunisation with chicken $\mathrm{Cll}$ in DBA/1J mice. Drugs were administered orally once a day from day 21 to 42 . (A) Arthritis score was monitored every 3 days after the booster immunisation. Data are expressed as mean $\pm S D(n=6)$. $* * * P<0.001$ versus vehicle-treated CIA control mice; two-way ANOVA. (B) Paw swelling was assessed using plethysmometer. Data are expressed as mean $\pm S D(n=6) . * P<0.05$ and $* * * P<0.001$ versus vehicle-treated CIA control mice; one-way ANOVA. (C) Representative pictures of hind paws on day 42 are showed. (D) Body weight was monitored after the booster immunisation. $* * * P<0.001$ versus vehicletreated CIA control mice; two-way ANOVA. CIA, collagen-induced arthritis; Cll, collagen type II; KLHTT, KanLu-Hsiao-Tu-Tan; MTX, methotrexate. 
Histopathological analysis of the CIA mice revealed inflammatory cell infiltration into articular tissues, exudates within the synovial space, synovial hyperplasia, and cartilage erosion. KLHTT-treated mice demonstrated well-preserved joint spaces with minimal inflammatory exudates, normal cartilage structure, and clear synovial spaces, along with improved histological arthritis severity scores (Fig. 3). MTX $(0.5 \mathrm{mg} / \mathrm{kg})$ was used as a positive control and showed comparable inhibitory effects with KLHTT in CIA mice (Fig. 2 and 3).

Figure 3. KLHTT reduces joint damage in CIA mice. CIA was induced by active immunisation with chicken CII in DBA/1J mice. Drugs were administered orally once a day from day 21 to 42. (A) Haematoxylin and eosin-stained joint sections from mice of different groups were prepared and pathogenic scores were determined. Original magnification 100x. Bar $=400 \mu \mathrm{m}$. Data are expressed as mean $\pm S D(n=6)$. $* P<0.05$ and $* * * P<0.001$ versus vehicle-treated CIA control mice; one-way ANOVA. CIA, collageninduced arthritis; ClI, collagen type II; KLHTT, Kan-Lu-Hsiao-Tu-Tan; MTX, methotrexate.

\subsection{KLHTT inhibits cytokine production in CIA mice}

The pathogenesis of RA involves activated $\mathrm{T}$ cells promoting macrophages to release pro-inflammatory cytokines [35]. Therefore, the levels of TNF- $a, \mathrm{IL}-1 \beta, \mathrm{IL}-6$, and IL-17 in hind paw homogenates and serum samples were measured by sandwich ELISA. KLHTT (50 and $100 \mathrm{mg} / \mathrm{kg}$ ) treatment inhibited the levels of IL-1 $\beta, I L-6, I L-17$, and TNF-a in paw homogenates (Fig. 4A) and serum samples (Fig. 4B) in CIA mice. These results indicated that KLHTT effectively attenuates inflammation in CIA mice.

Figure 4. KLHTT inhibits pro-inflammatory cytokine production in CIA mice. CIA was induced by active immunisation with chicken $\mathrm{ClI}$ in DBA/1J mice. Drugs were administered orally once a day from day 21 to 42. The levels of cytokines in hind paw homogenates $(A)$ and serum (B) from CIA mice were measured on day 42 by enzyme-linked immunosorbent assay. Data are expressed as mean $\pm S D(n=6) . * P<0.05$, $* * P<0.01$, and $* * * P<0.001$ versus vehicle-treated CIA control mice; one-way ANOVA. CIA, collageninduced arthritis; CII, collagen type II; IL, interleukin; KLHTT, Kan-Lu-Hsiao-Tu-Tan; TNF-a, tumour necrosis factor-a.

\subsection{KLHTT reduces oxidative stress in CIA mice}


RA patients exhibit high level of oxidative stress, which correlates with joint inflammation and may contribute to the chronicity of RA [36]. Significantly elevated levels of MDA and $\mathrm{H}_{2} \mathrm{O}_{2}$ were noted in the hind paw homogenates of CIA mice. KLHTT ( 50 and $100 \mathrm{mg} / \mathrm{kg}$ ) significantly reduced the levels of MDA (Fig. $5 \mathrm{~A}$ ) and $\mathrm{H}_{2} \mathrm{O}_{2}$ (Fig. 5B). These data showed that $\mathrm{KLHTT}$ protects mice from oxidative damage, which may have contributed to the amelioration of CIA.

Figure 5. KLHTT reduces the levels of MDA and $\mathrm{H}_{2} \mathrm{O}_{2}$ in CIA mice. $\mathrm{CIA}$ was induced by active immunisation with chicken $\mathrm{Cll}$ in $\mathrm{DBA} / 1 \mathrm{~J}$ mice. Drugs were administered orally once a day from day 21 to 42. $\mathrm{H}_{2} \mathrm{O}_{2}$ (a ROS marker) and MDA (a lipid peroxidation marker) were determined on day 42 by a hydrogen peroxide assay kit and thiobarbituric acid reactive substances assay, respectively. Data are expressed as mean $\pm \mathrm{SD}(\mathrm{n}=6) . * P<0.05, * * P<0.01$, and $* * * P<0.001$ versus vehicle-treated CIA control mice; one-way ANOVA. CIA, collagen-induced arthritis; $\mathrm{Cll}$, collagen type $\mathrm{Il}_{;} \mathrm{H}_{2} \mathrm{O}_{2}$, hydrogen peroxide; KLHTT, Kan-Lu-Hsiao-Tu-Tan; MDA, malondialdehyde.

\subsection{KLHTT inhibits CII-specific antibody production and splenocyte proliferation in CIA mice}

Autoantibodies targeting IgG play a major role in RA. Similarly, elevated levels of IgG1 and IgG2a antibodies were detected in serum samples from CIA mice. KLHTT significantly suppressed IgG1 and IgG2a antibody production (Fig. 6A). Furthermore, KLHTT significantly inhibited the proliferation of CIIinduced splenocytes (Fig. 6B).

Figure 6. KLHTT inhibits anti-IgG Cll antibody production and splenocyte proliferation in CIA mice. CIA was induced by active immunisation with chicken CII in DBA/1 J mice. Drugs were administered orally once a day from day 21 to 42. (A) The levels of anti-CII IgG1 and IgG2a antibodies were detected on day 42 using enzyme-linked immunosorbent assay. (B) Splenocytes were cultured with Cll for $40 \mathrm{~h}$, and then cell proliferation was measured by incorporation of $\left[{ }^{3} \mathrm{H}\right]$-thymidine. Data are expressed as mean $\pm \mathrm{SD}$ $(\mathrm{n}=6) . * * P<0.01$, and $* * * P<0.001$ versus vehicle-treated CIA control mice; one-way ANOVA. CIA, collagen-induced arthritis; Cll, collagen type Il; KLHTT, Kan-Lu-Hsiao-Tu-Tan.

\subsection{KLHTT reduces the levels of splenic Th1 and Th17 cells in CIA mice}

The pro-inflammatory Th1 and Th17 cell axes play crucial roles in RA. The levels of splenic Th1 and Th17 cells were higher after $\mathrm{Cll}$ induction. KLHTT significantly decreased the numbers of $\mathrm{CD} 4^{+} \mathrm{IFNY}{ }^{+} \mathrm{Th} 1$ and CD4 ${ }^{+}$IL17A ${ }^{+}$Th17 cells (Fig. 7). KLHTT also mitigated the levels of pro-inflammatory cytokines in CIA 
mice (Fig. 4). These results indicated that KLHTT decreases splenic pro-inflammatory Th1 and Th17 cells in CIA mice.

Figure 7. KLHTT reduces the levels of splenic Th1 and Th17 cells in CIA mice. CIA was induced by active immunisation with chicken $\mathrm{ClI}$ in DBA/1J mice. Drugs were administered orally once a day from day 21 to 42. (A) Splenocytes were cultured with CII for $2 d$, and then stained with PE-conjugated anti-CD4 antibodies followed by FITC-conjugated anti-IL-17A or anti-IFN-y antibodies. Samples were analysed by flow cytometry. (B) Bars display the mean $\pm \mathrm{SD}(\mathrm{n}=6)$. $* * * P<0.001$ versus vehicle-treated CIA control mice; one-way ANOVA. CIA, collagen-induced arthritis; Cll, collagen type II; IL-17, interleukin 17; IFN-ץ, interferon gamma; KLHTT, Kan-Lu-Hsiao-Tu-Tan.

\section{Discussion}

RA is a chronic autoimmune inflammatory disease [1]. Patients with RA have systemic inflammatory comorbidities. The therapeutic armamentarium for RA has expanded from analgesics and nonsteroidal anti-inflammatory drugs to biological disease-modifying anti-rheumatic drugs and conventional diseasemodifying anti-rheumatic drugs; however, these available therapies may cause adverse reactions and fail to achieve long-term remission [37]. Therefore, the development of new drugs is required to improve the treatment of RA.

KLHTT is a well-known CM and has been used to treat inflammatory diseases [22]. In this study, we investigated the anti-arthritic effect of KLHTT in CIA mice. Mice actively immunised with Cll develop CIA, which closely resembles human RA. CIA mice showed paw erythema and swelling, synovitis, cartilage damage, and bone erosion [35]. KLHTT reduced arthritis severity scores and paw swelling, and restored body weight in CIA mice. KLHTT also decreased inflammatory cell infiltration. Both in CIA and human RA, pro-inflammatory cytokines such as TNF-a, IL-1 $\beta$, IL-6, and IL-17 trigger autoimmune reactions and enhance chronic inflammation in synovial tissues [38,39]. These pro-inflammatory cytokines activate synovial fibroblasts and chondrocytes to produce enzymes which degrade collagen and proteoglycans, thus damaging adjacent joint tissues [40]. KLHTT significantly reduced the levels of TNF-a, IL-1 $\beta$, IL-6, and IL-17 in serum samples and joint homogenates. Therefore, KLHTT exerts local and systemic antiinflammatory effects, which may explain its anti-arthritic activity.

Autoantibodies such as rheumatoid factor and ACPAs can be detected in $50-80 \%$ of RA patients. Increased levels of anti-CII IgG correlate with elevated TNF- $\alpha$ and IL-6 in RA patients [41]. In CIA mice, antiCll antibodies initiate arthritis and Cll-reactive $T$ cells promote the progression of the disease [42]. In this study, KLHTT reduced the levels of anti-CII IgG1 and IgG2a in serum samples from CIA mice. Anti-Cll IgG2 autoantibodies are the predominant subclass of autoantibodies in CIA mice [35]. Also, KLHTT inhibited Cll-induced splenocyte proliferation and reduced the levels of splenic Th1 and Th17 cells. These results indicate that KLHTT has immunomodulatory effects in CIA. 
Oxidative stress is involved in the pathogenesis of RA [36,43]. In this study, KLHTT significantly decreased the levels of $\mathrm{H}_{2} \mathrm{O}_{2}$ (a ROS marker) and MDA (a lipid peroxidation marker) in joint homogenates from CIA mice. MDA-related reactions are highly immunogenic. MDA levels correlate with RA severity and can be used to predict RA severity [43]. In addition, autoreactive T cells such as Th1 and Th17 cells are crucial in the pathogenesis of RA [44]. The newly diagnosed RA patients have higher levels of serum Th1 and Th17 cells [45]. RA patients show increased Th17 cell infiltration in the synovium [46,47]. Infliximab, an anti-TNF-a antibody, promotes Th1 cell apoptosis in RA patients, thus impeding RA progression [48]. Adalimumab, another anti-TNF-a drug, mitigates the homing of Th17 cells to the synovium, consequently improving joint damage [49]. In this study, KLHTT showed a decrease effect in the levels of splenic Th1 and Th17 cells. The levels of pro-inflammatory cytokines, such as IL-1 $\beta$, IL-6, IL-17, and TNF-a, were also inhibited by KLHTT. Therefore, we suggest that the regulation of Th1 and Th17 cells is also involved in the anti-arthritic effects of KLHTT.

We identified eight flavonoids from KLHTT, including chrysin 6- $C$-arabinoside-8- $C$-glucoside, chrysin 6- $C$ glucoside-8- $C$-arabinoside, baicalin, norwogonin-7- $O-\beta_{D^{-}}$-glucuronide, chrysin 7- $O-\beta_{-}$-glucuronide, oroxylin A 7- $O-\beta_{-D}$-glucuronide, wogonoside, and baicalein. Previous studies have reported that baicalin ameliorated CIA in mice by down-regulating Janus kinase 1/signal transducer and activator of transcription 3 signalling and inhibiting IL-17-mediated joint inflammation [50,51]. Baicalein also suppressed human RA fibroblast-like synoviocyte proliferation induced by IL-1 $\beta$ [52]. Intraperitoneal administration of oroxylin A ameliorated CIA in mice and reduced the levels of IL-1 $\beta$ and IL- 6 in human RA fibroblast-like synoviocyte stimulated by TNF-a [53]. Chrysin suppressed nuclear factor-KB and high-mobility group box chromosomal protein in human osteoarthritis chondrocytes stimulated by IL-1 $\beta$ $[54,55]$. A CM formulation contains various herbs and exhibits synergistic effects [56]. Observably, the anti-arthritic effects of KLHTT were comparable to those of MTX. However, more researches are required to prove the synergistic effects of KLHTT in treating RA.

\section{Conclusion}

In summary, our results indicate that KLHTT, a CM formulation, shows significantly anti-inflammatory effects, antioxidant activities, and immunomodulatory functions in CIA mice. The present study also demonstrates that KLHTT has potential to treat RA.

\section{Abbreviations}

ACPA

anti-citrullinated protein antibody

CIA

collagen-induced arthritis

Cll 
collagen type II

$\mathrm{CM}$

Chinese medicine

DMARD

disease-modifying anti-rheumatic drugs

ELISA

enzyme-linked immunosorbent assay

IL

interleukin

KLHTT

Kan-Lu-Hsiao-Tu-Tan

MDA

malondialdehyde

MTX

methotrexate

RA

rheumatoid arthritis

ROS

reactive oxygen species

TNF

tumour necrosis factor

UPLC-MS/MS

ultra-performance liquid chromatography-tandem mass spectrometry

\section{Declarations}

\section{Ethics approval and consent to participate}

Not applicable.

\section{Consent for publication}

Not applicable.

\section{Availability of data and materials}

Upon request, data used to support the findings of this study are available from the corresponding authors. 


\section{Competing interests}

The authors declare no competing interests.

\section{Funding}

This study was supported by grants from the Ministry of Science Technology (MOST 106-2320-B-255003-MY3 and MOST 104-2320-B-255-004-MY3), Chang Gung University of Science and Technology (ZRRPF3H0101 and ZRRPF3H0111), and Chang Gung Memorial Hospital (CMRPF1F0011 3, CMRPF1F0061 3, CMRPF1G0241 3, CMRPG3K0161, and BMRP450), Taiwan. The funders had no role in this research.

\section{Authors' contributions}

CCC performed the experiments, analyzed the data, and wrote the paper. YRL and KHL performed the experiments and analyzed the data. WJC and SCL revised the paper and figures. YHW and PJC provided technical details and results validation. SHY and TLH supervised the experiments and revised the manuscript. All authors read and approved the final manuscript.

\section{Acknowledgements}

The authors thank Editage for English language editing. Miss Ingrid Kuo at the Center for Big Data Analytics and Statistics (Grant CLRPG 3D0045) of Chang Gung Memorial Hospital helps in creating the illustrations.

\section{References}

1. van der Woude $D$, van der Helm-van Mil AHM. Update on the epidemiology, risk factors, and disease outcomes of rheumatoid arthritis. Best practice research Clinical rheumatology. 2018;32(2):174-87.

2. Katz P. Causes and consequences of fatigue in rheumatoid arthritis. Curr Opin Rheumatol. 2017;29(3):269-76.

3. DeQuattro K, Imboden JB. Neurologic Manifestations of Rheumatoid Arthritis. Rheum Dis Clin North Am. 2017;43(4):561-71.

4. Krause A, Rubbert-Roth A. Pulmonary involvement in rheumatoid arthritis. Zeitschrift fur Rheumatologie 2019. 
5. Sinnathurai P, Capon A, Buchbinder R, Chand V, Henderson L, Lassere M, March L. Cardiovascular risk management in rheumatoid and psoriatic arthritis: online survey results from a national cohort study. BMC rheumatology. 2018;2:25.

6. Sruamsiri R, Kaneko Y, Mahlich J. The underrated prevalence of depression in Japanese patients with rheumatoid arthritis - evidence from a Nationwide survey in Japan. BMC rheumatology. 2017;1:5.

7. Turk SA, Rasch LA, van Schaardenburg D, Lems WF, Sanberg M, van Tuyl LHD, Ter Wee MM. Pain, sleep and emotional well-being explain the lack of agreement between physician- and patientperceived remission in early rheumatoid arthritis. BMC rheumatology. 2018;2:16.

8. Fazal SA, Khan M, Nishi SE, Alam F, Zarin N, Bari MT, Ashraf GM. A Clinical Update and Global Economic Burden of Rheumatoid Arthritis. Endocr Metab Immune Disord Drug Targets. 2018;18(2):98-109.

9. Toye F, Seers K, Barker KL. Living life precariously with rheumatoid arthritis - a mega-ethnography of nine qualitative evidence syntheses. BMC rheumatology. 2019;3:5.

10. Yasuda K, Takeuchi Y, Hirota K. The pathogenicity of Th17 cells in autoimmune diseases. Seminars in immunopathology 2019.

11. Yayikci Yl, Karadag A. Effects of Conventional and Biological Drugs Used for the Treatment of Rheumatoid Arthritis on the Quality of Life and Depression. The Eurasian journal of medicine. 2019;51(1):12-6.

12. Smolen JS, Aletaha D, McInnes IB. Rheumatoid arthritis. Lancet. 2016;388(10055):2023-38.

13. Hu XX, Wu YJ, Zhang J, Wei W. T-cells interact with B cells, dendritic cells, and fibroblast-like synoviocytes as hub-like key cells in rheumatoid arthritis. Int Immunopharmacol. 2019;70:428-34.

14. Cecchi I, Arias de la Rosa I, Menegatti E, Roccatello D, Collantes-Estevez E, Lopez-Pedrera C, Barbarroja N. Neutrophils: Novel key players in Rheumatoid Arthritis. Current and future therapeutic targets. Autoimmun rev. 2018;17(11):1138-49.

15. Siouti E, Andreakos E. The many facets of macrophages in rheumatoid arthritis. Biochemical pharmacology 2019.

16. Wang SP, Lin SC, Li S, Chao YH, Hwang GY, Lin CC. Potent Antiarthritic Properties of Phloretin in Murine Collagen-Induced Arthritis. Evidence-based complementary alternative medicine: eCAM. 2016;2016:9831263.

17. Aletaha D, Neogi T, Silman AJ, Funovits J, Felson DT, Bingham CO 3rd, Birnbaum NS, Burmester GR, Bykerk VP, Cohen MD, et al. 2010 Rheumatoid arthritis classification criteria: an American College of Rheumatology/European League Against Rheumatism collaborative initiative. Arthritis rheumatism. 2010;62(9):2569-81.

18. Hadjigogos K. The role of free radicals in the pathogenesis of rheumatoid arthritis. Panminerva medica. 2003;45(1):7-13.

19. Ali AM, Habeeb RA, El-Azizi NO, Khattab DA, Abo-Shady RA, Elkabarity RH. Higher nitric oxide levels are associated with disease activity in Egyptian rheumatoid arthritis patients. Revista brasileira de 
reumatologia. 2014;54(6):446-51.

20. Mateen S, Rehman MT, Shahzad S, Naeem SS, Faizy AF, Khan AQ, Khan MS, Husain FM, Moin S. Anti-oxidant and anti-inflammatory effects of cinnamaldehyde and eugenol on mononuclear cells of rheumatoid arthritis patients. Eur J Pharmacol. 2019;852:14-24.

21. Caplazi P, Baca M, Barck K, Carano RA, DeVoss J, Lee WP, Bolon B, Diehl L. Mouse Models of Rheumatoid Arthritis. Veterinary pathology. 2015;52(5):819-26.

22. Yingwei S, Haibo Y, Yaguang C, Lei Z. Kan-Lu-Hsiao-Tu-Tan treats rheumatism: 4 cases reports (Print in Chinese). International Journal of Traditional Chinese Medicine. 2015;37:461-2.

23. Wei Shucheng Y, Donghui Yu, Lianhe W, Jian T, Siyuan, Yan B. Research Overview of Ganlu Xiaodu Pills in Treatign Disease with Syndrome of Damp-heat. Clinical Journal of Traditional Chinese Medicine. 2017;29:735-8.

24. Xu Y. Variant Ganlu Xiaodu Dan treating chronic dermatitis in 47 cases (Print in Chinese). Clinical Journal of Traditional Chinese Medicine. 2010;22(6):514-5.

25. Chiang CC, Cheng WJ, Lin CY, Lai KH, Ju SC, Lee C, Yang SH, Hwang TL. Kan-Lu-Hsiao-Tu-Tan, a traditional Chinese medicine formula, inhibits human neutrophil activation and ameliorates imiquimod-induced psoriasis-like skin inflammation. J Ethnopharmacol. 2020;246:112246.

26. Chen DY, Lin CC, Chen YM, Chao YH, Yang DH. Dextromethorphan Exhibits Anti-inflammatory and Immunomodulatory Effects in a Murine Model of Collagen-Induced Arthritis and in Human Rheumatoid Arthritis. Sci Rep. 2017;7(1):11353.

27. Hsieh YJ, Yen MH, Chiang YW, Yeh CF, Chiang LC, Shieh DE, Yeh I, Chang JS. Gan-Lu-Siao-Du-yin, a prescription of traditional Chinese medicine, inhibited enterovirus 71 replication, translation, and virus-induced cell apoptosis. J Ethnopharmacol. 2016;185:132-9.

28. Zhi HJ, Zhu HY, Zhang YY, Lu Y, Li H, Chen DF. In vivo effect of quantified flavonoids-enriched extract of Scutellaria baicalensis root on acute lung injury induced by influenza A virus. Phytomedicine: international journal of phytotherapy phytopharmacology. 2019;57:105-16.

29. Xu J, Yu Y, Shi R, Xie G, Zhu Y, Wu G, Qin M. Organ-Specific Metabolic Shifts of Flavonoids in Scutellaria baicalensis at Different Growth and Development Stages. Molecules (Basel, Switzerland) 2018, 23(2).

30. Sameena Y, Chandrasekaran S, Israel VMVE. Inclusion complexation between baicalein and betacyclodextrin and the influence of beta-cyclodextrin on the binding of baicalein with DNA: a spectroscopic approach. J Biomol Struct Dyn. 2016;34(7):1395-408.

31. Qiao X, Li R, Song W, Miao WJ, Liu J, Chen HB, Guo DA, Ye M. A targeted strategy to analyze untargeted mass spectral data: Rapid chemical profiling of Scutellaria baicalensis using ultra-high performance liquid chromatography coupled with hybrid quadrupole orbitrap mass spectrometry and key ion filtering. Journal of chromatography A. 2016;1441:83-95.

32. Yu C, Zhang Z, Zhang H, Zhen Z, Calway T, Wang Y, Yuan CS, Wang CZ. Pretreatment of baicalin and wogonoside with glycoside hydrolase: a promising approach to enhance anticancer potential. Oncol Rep. 2013;30(5):2411-8. 
33. Ye G, Tang YH, Wang GY, Li ZX, Zhu HY, Ma CH, Sun ZL, Huang CG. Characterization of the multiple absorbed constituents in rats after oral administration of Chai-Huang decoction by liquid chromatography coupled with electrospray-ionization mass spectrometry. Chem Biodivers. 2010;7(12):2917-30.

34. Singh R, Wu B, Tang L, Liu Z, Hu M. Identification of the position of mono-O-glucuronide of flavones and flavonols by analyzing shift in online UV spectrum (lambdamax) generated from an online diode array detector. J Agric Food Chem. 2010;58(17):9384-95.

35. Miyoshi M, Liu S. Collagen-Induced Arthritis Models. Methods in molecular biology (Clifton, $\mathrm{NJ}$ ) 2018, 1868:3-7.

36. Mateen S, Moin S, Khan AQ, Zafar A, Fatima N. Increased Reactive Oxygen Species Formation and Oxidative Stress in Rheumatoid Arthritis. PloS one. 2016;11(4):e0152925.

37. McInnes IB, O'Dell JR. State-of-the-art: rheumatoid arthritis. Ann Rheum Dis. 2010;69(11):1898-906.

38. Noack M, Miossec P. Selected cytokine pathways in rheumatoid arthritis. Semin Immunopathol. 2017;39(4):365-83.

39. Feldmann M, Maini SR. Role of cytokines in rheumatoid arthritis: an education in pathophysiology and therapeutics. Immunological reviews. 2008;223:7-19.

40. Lubberts E, van den Berg WB. Cytokines in the pathogenesis of rheumatoid arthritis and collageninduced arthritis. Adv Exp Med Biol. 2003;520:194-202.

41. Kim WU, Yoo WH, Park W, Kang YM, Kim SI, Park JH, Lee SS, Joo YS, Min JK, Hong YS, et al. IgG antibodies to type II collagen reflect inflammatory activity in patients with rheumatoid arthritis. $\mathrm{J}$ Rhuematol. 2000;27(3):575-81.

42. Nandakumar KS, Backlund J, Vestberg M, Holmdahl R. Collagen type II (CII)-specific antibodies induce arthritis in the absence of $\mathrm{T}$ or $\mathrm{B}$ cells but the arthritis progression is enhanced by Cll-reactive T cells. Arthritis research therapy. 2004;6(6):R544-50.

43. Quinonez-Flores CM, Gonzalez-Chavez SA, Del Rio Najera D, Pacheco-Tena C. Oxidative Stress Relevance in the Pathogenesis of the Rheumatoid Arthritis: A Systematic Review. BioMed research international. 2016;2016:6097417.

44. Damsker JM, Hansen AM, Caspi RR. Th1 and Th17 cells: adversaries and collaborators. Ann N Y Acad Sci. 2010;1183:211-21.

45. Bazzazi H, Aghaei M, Memarian A, Asgarian-Omran H, Behnampour N, Yazdani Y. Th1-Th17 Ratio as a New Insight in Rheumatoid Arthritis Disease. Iran J Allergy Asthma Immunol. 2018;17(1):68-77.

46. Awasthi A, Kuchroo VK. Th17 cells: from precursors to players in inflammation and infection. Int Immunol. 2009;21(5):489-98.

47. Kotake S, Udagawa N, Takahashi N, Matsuzaki K, Itoh K, Ishiyama S, Saito S, Inoue K, Kamatani N, Gillespie MT, et al. IL-17 in synovial fluids from patients with rheumatoid arthritis is a potent stimulator of osteoclastogenesis. J Clin Investig. 1999;103(9):1345-52. 
48. Herman S, Zurgil N, Machlav S, Shinberg A, Langevitz P, Ehrenfeld M, Deutsch M. Distinct effects of anti-tumor necrosis factor combined therapy on $\mathrm{TH} 1 / \mathrm{TH} 2$ balance in rheumatoid arthritis patients. Clinical vaccine immunology: CVI. 2011;18(7):1077-82.

49. Aerts NE, De Knop KJ, Leysen J, Ebo DG, Bridts CH, Weyler JJ, Stevens WJ, De Clerck LS. Increased IL-17 production by peripheral T helper cells after tumour necrosis factor blockade in rheumatoid arthritis is accompanied by inhibition of migration-associated chemokine receptor expression. Rheumatology. 2010;49(12):2264-72.

50. Yang $X$, Yang J, Zou H. Baicalin inhibits IL-17-mediated joint inflammation in murine adjuvantinduced arthritis. Clin Dev Immunol. 2013;2013:268065.

51. Wang C, Song Y, Wang X, Mao R, Song L. Baicalin Ameliorates Collagen-Induced Arthritis Through the Suppression of Janus Kinase 1 (JAK1)/Signal Transducer and Activator of Transcription 3 (STAT3) Signaling in Mice. Medical science monitor: international medical journal of experimental clinical research. 2018;24:9213-22.

52. Chen S, Yang Y, Feng H, Wang H, Zhao R, Liu H. Baicalein inhibits interleukin-1beta-induced proliferation of human rheumatoid arthritis fibroblast-like synoviocytes. Inflammation. 2014;37(1):163-9.

53. Wang YL, Gao JM, Xing LZ. Therapeutic potential of Oroxylin A in rheumatoid arthritis. Int Immunopharmacol. 2016;40:294-9.

54. Zhang C, Yu W, Huang C, Ding Q, Liang C, Wang L, Hou Z, Zhang Z. Chrysin protects human osteoarthritis chondrocytes by inhibiting inflammatory mediator expression via HMGB1 suppression. Mol Med Rep. 2019;19(2):1222-9.

55. Zheng W, Tao Z, Cai L, Chen C, Zhang C, Wang Q, Ying X, Hu W, Chen H. Chrysin Attenuates IL-1 $\beta$ Induced Expression of Inflammatory Mediators by Suppressing NF-кB in Human Osteoarthritis Chondrocytes. Inflammation. 2017;40(4):1143-54.

56. Ho LJ, Chang WL, Chen A, Chao P, Lai JH. Differential immunomodulatory effects by Tripterygium wilfordii Hook f-derived refined extract PG27 and its purified component PG490 (triptolide) in human peripheral blood T cells: potential therapeutics for arthritis and possible mechanisms explaining in part Chinese herbal theory "Junn-Chenn-Zuou-SS". Journal of translational medicine. 2013;11:294.

\section{Table}

Table 1. UV and multi-stage mass spectrometry data for the identification of the constituents of Kan-Lu-Hsiao-Tu-Tan extract. 


\begin{tabular}{|c|c|c|c|c|c|}
\hline No. & $t_{\mathrm{R}}(\min )$ & Formula & (-)-ESI-MS/MS Fragment Ions & $\lambda_{\max }(\mathrm{nm})$ & Identification \\
\hline 1 & 7.269 & $\mathrm{C}_{26} \mathrm{H}_{28} \mathrm{O}_{13}$ & $547,487,457,427,367,337$ & 271,317 & Chrysin 6- $C$-arabinoside-8- $C$-glucoside \\
\hline 2 & 8.249 & $\mathrm{C}_{26} \mathrm{H}_{28} \mathrm{O}_{13}$ & $547,457,427,367,337$ & 271,317 & Chrysin 6- $C$-glucoside-8- $C$-arabinoside \\
\hline 3 & 12.674 & $\mathrm{C}_{21} \mathrm{H}_{18} \mathrm{O}_{11}$ & $445,269,251,223,197,113$ & 276,316 & Baicalin \\
\hline 4 & 14.321 & $\mathrm{C}_{21} \mathrm{H}_{18} \mathrm{O}_{11}$ & $445,269,241,225,171$ & 278,347 & Norwogonin-7- $O-\beta{ }^{-} \mathrm{D}-$ glucuronide \\
\hline 5 & 15.209 & $\mathrm{C}_{21} \mathrm{H}_{18} \mathrm{O}_{10}$ & $429,253,209,143,113$ & 267 & Chrysin $7-O-\beta-_{-}$-glucuronide \\
\hline 6 & 15.455 & $\mathrm{C}_{22} \mathrm{H}_{20} \mathrm{O}_{11}$ & $459,283,268$ & 271,311 & Oroxylin A 7-O- $\beta_{-\mathrm{D}}^{-}$-glucuronide \\
\hline 7 & 16.345 & $\mathrm{C}_{22} \mathrm{H}_{20} \mathrm{O}_{11}$ & $459,283,268$ & 273,340 & Wogonoside \\
\hline 8 & 19.220 & $\mathrm{C}_{15} \mathrm{H}_{10} \mathrm{O}_{5}$ & $269,251,241,223,195,169,136$ & 275,324 & Baicalein \\
\hline
\end{tabular}

\section{Figures}
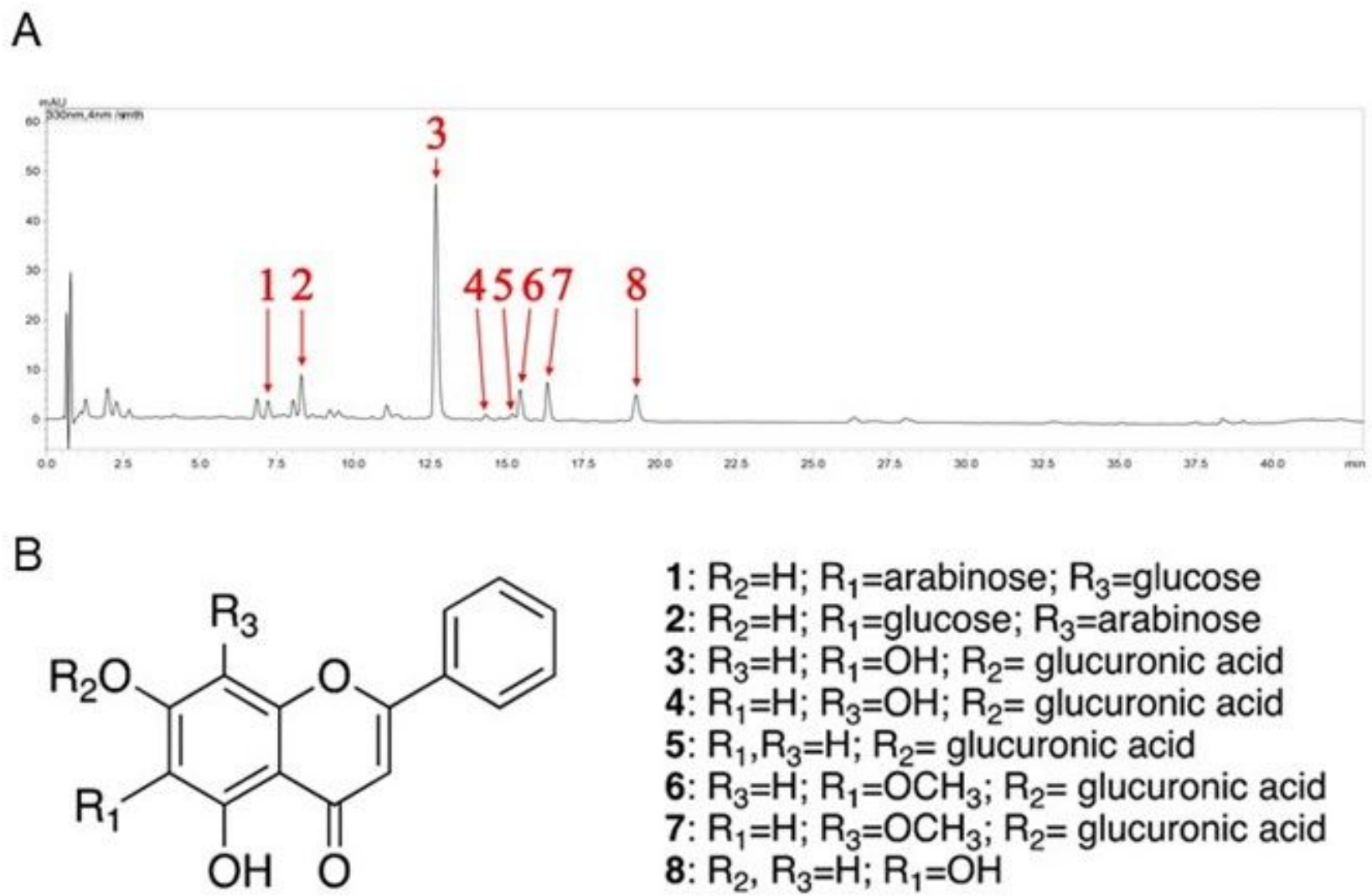

1: $\mathrm{R}_{2}=\mathrm{H} ; \mathrm{R}_{1}=$ arabinose; $\mathrm{R}_{3}=$ glucose

2: $\mathrm{R}_{2}=\mathrm{H} ; \mathrm{R}_{1}=$ glucose; $\mathrm{R}_{3}=$ arabinose

3: $\mathrm{R}_{3}=\mathrm{H} ; \mathrm{R}_{1}=\mathrm{OH} ; \mathrm{R}_{2}=$ glucuronic acid

4: $\mathrm{R}_{1}=\mathrm{H} ; \mathrm{R}_{3}=\mathrm{OH} ; \mathrm{R}_{2}=$ glucuronic acid

5: $\mathrm{R}_{1}, \mathrm{R}_{3}=\mathrm{H} ; \mathrm{R}_{2}=$ glucuronic acid

6: $\mathrm{R}_{3}=\mathrm{H} ; \mathrm{R}_{1}=\mathrm{OCH}_{3} ; \mathrm{R}_{2}=$ glucuronic acid

7: $\mathrm{R}_{1}=\mathrm{H} ; \mathrm{R}_{3}=\mathrm{OCH}_{3} ; \mathrm{R}_{2}=$ glucuronic acid

8: $R_{2}, R_{3}=H ; R_{1}=O H$

\section{Figure 1}

The chemical fingerprint of KLHTT. (A) Ultra-performance liquid chromatography with photodiode array detector chromatogram $(\lambda=330 \mathrm{~nm}$ ) of KLHTT extract. (B) The flavonoid derivatives in KLHTT extract were identified by comparing specific liquid chromatography-tandem mass spectrometry monitoring fragmentations with previously reported data, and were determined to be: chrysin 6-C-arabinoside-8-Cglucoside (1), chrysin 6-C-glucoside-8-C-arabinoside (2), baicalin (3), norwogonin-7-O- $\beta$-D-glucuronide (4), 
chrysin 7-0- $\beta$-D-glucuronide (5), oroxylin A 7-O- $\beta$-D-glucuronide (6), wogonoside (7), and baicalein (8). KLHTT, Kan-Lu-Hsiao-Tu-Tan.
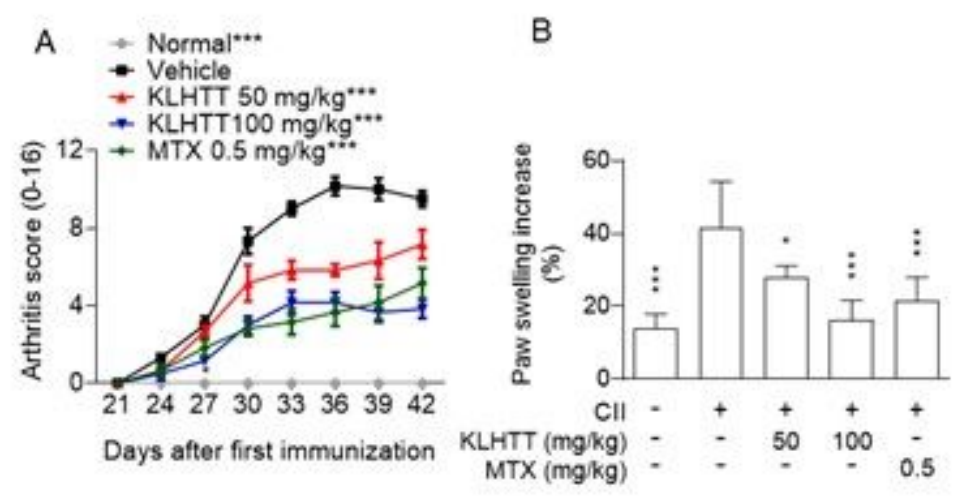

C
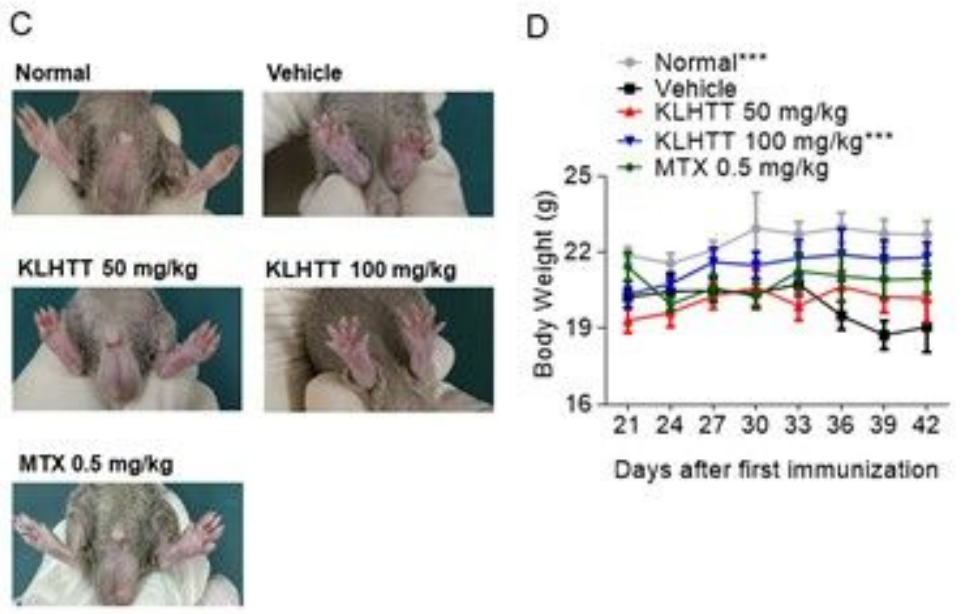

\section{Figure 2}

KLHTT ameliorates $\mathrm{ClA}$ severity. $\mathrm{ClA}$ was induced by active immunisation with chicken $\mathrm{Cll}$ in $\mathrm{DBA} / 1 \mathrm{~J}$ mice. Drugs were administered orally once a day from day 21 to 42. (A) Arthritis score was monitored every 3 days after the booster immunisation. Data are expressed as mean $\pm \operatorname{SD}(n=6) . * * * P<0.001$ versus vehicle-treated CIA control mice; two-way ANOVA. (B) Paw swelling was assessed using plethysmometer. Data are expressed as mean $\pm S D(n=6) . * P<0.05$ and $* * * P<0.001$ versus vehicletreated CIA control mice; one-way ANOVA. (C) Representative pictures of hind paws on day 42 are showed. (D) Body weight was monitored after the booster immunisation. $* * * \mathrm{P}<0.001$ versus vehicletreated CIA control mice; two-way ANOVA. CIA, collagen-induced arthritis; Cll, collagen type Il; KLHTT, KanLu-Hsiao-Tu-Tan; MTX, methotrexate. 

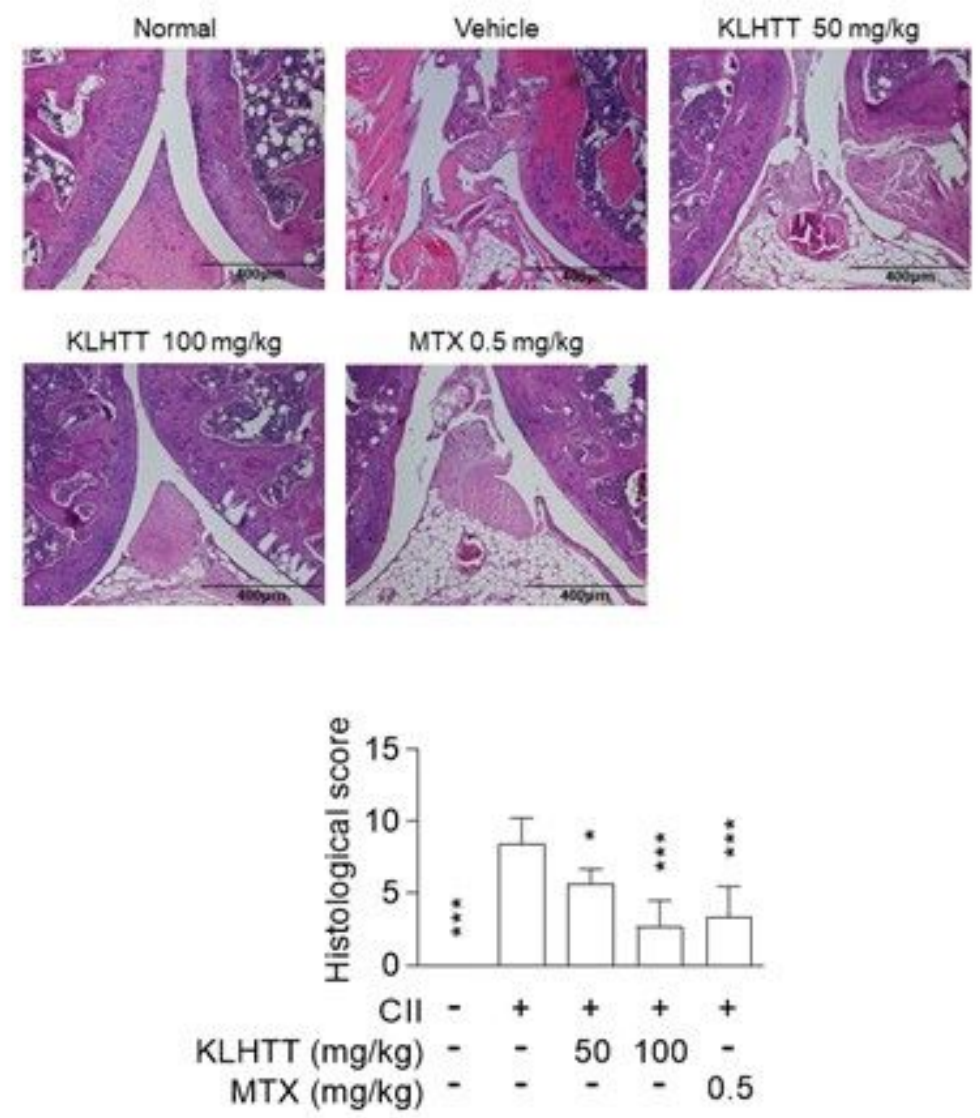

\section{Figure 3}

$\mathrm{KLHTT}$ reduces joint damage in CIA mice. CIA was induced by active immunisation with chicken $\mathrm{Cll}$ in DBA/1J mice. Drugs were administered orally once a day from day 21 to 42. (A) Haematoxylin and eosinstained joint sections from mice of different groups were prepared and pathogenic scores were determined. Original magnification 100x. Bar $=400 \mu \mathrm{m}$. Data are expressed as mean $\pm S D(n=6)$. $* \mathrm{P}<0.05$ and $* * * \mathrm{P}<0.001$ versus vehicle-treated CIA control mice; one-way ANOVA. CIA, collageninduced arthritis; Cll, collagen type Il; KLHTT, Kan-Lu-Hsiao-Tu-Tan; MTX, methotrexate. 

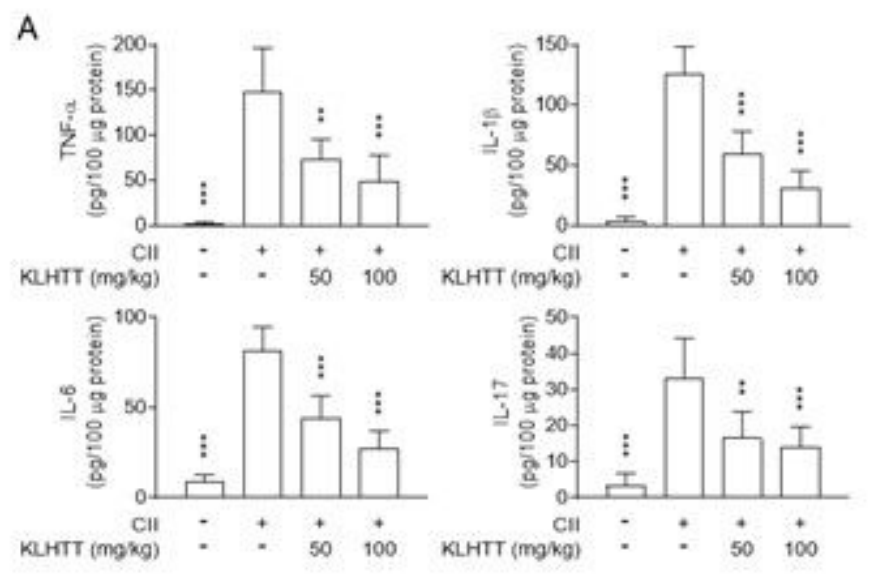

B
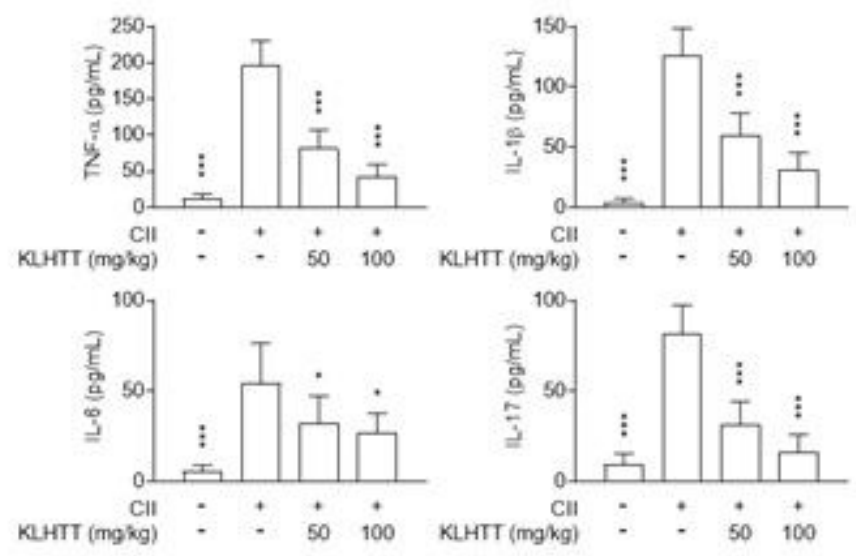

Figure 4

KLHTT inhibits pro-inflammatory cytokine production in CIA mice. CIA was induced by active immunisation with chicken $\mathrm{Cll}$ in $\mathrm{DBA} / 1 \mathrm{~J}$ mice. Drugs were administered orally once a day from day 21 to 42. The levels of cytokines in hind paw homogenates $(A)$ and serum (B) from CIA mice were measured on day 42 by enzyme-linked immunosorbent assay. Data are expressed as mean $\pm S D(n=6) . * P<0.05$, $* * \mathrm{P}<0.01$, and $* * * \mathrm{P}<0.001$ versus vehicle-treated CIA control mice; one-way ANOVA. CIA, collageninduced arthritis; CII, collagen type II; IL, interleukin; KLHTT, Kan-Lu-Hsiao-Tu-Tan; TNF-a, tumour necrosis factor-a. 
A

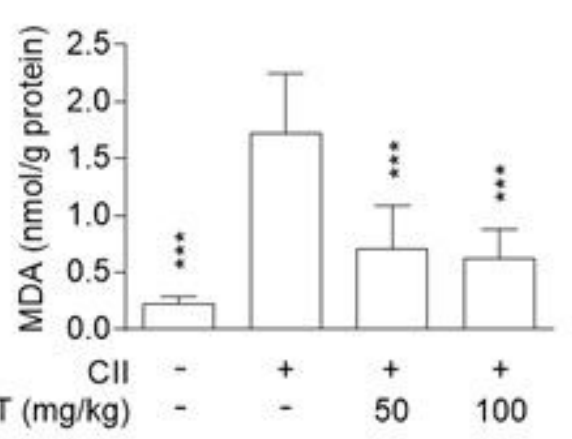

B

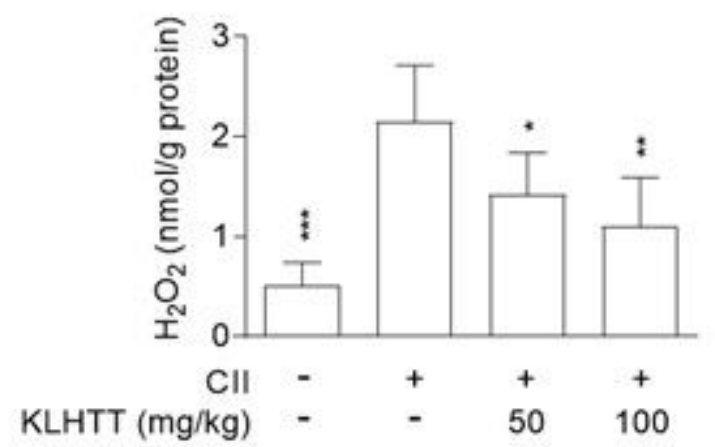

\section{Figure 5}

KLHTT reduces the levels of MDA and H2O2 in CIA mice. CIA was induced by active immunisation with chicken Cll in DBA/1J mice. Drugs were administered orally once a day from day 21 to 42 . H2O2 (a ROS marker) and MDA (a lipid peroxidation marker) were determined on day 42 by a hydrogen peroxide assay kit and thiobarbituric acid reactive substances assay, respectively. Data are expressed as mean \pm SD $(\mathrm{n}=6) . * \mathrm{P}<0.05, * * \mathrm{P}<0.01$, and $* * * \mathrm{P}<0.001$ versus vehicle-treated CIA control mice; one-way ANOVA. CIA, collagen-induced arthritis; CIl, collagen type II; H2O2, hydrogen peroxide; KLHTT, Kan-Lu-Hsiao-TuTan; MDA, malondialdehyde. 
A

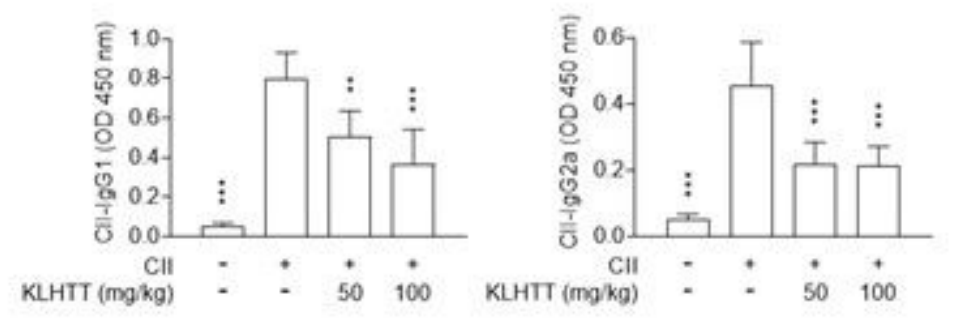

B

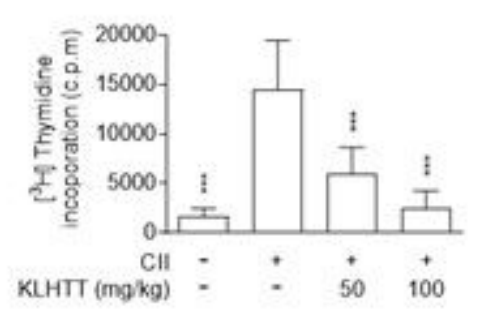

\section{Figure 6}

KLHTT inhibits anti-IgG Cll antibody production and splenocyte proliferation in CIA mice. CIA was induced by active immunisation with chicken $\mathrm{Cll}$ in DBA/1J mice. Drugs were administered orally once a day from day 21 to 42. (A) The levels of anti-CII IgG1 and IgG2a antibodies were detected on day 42 using enzymelinked immunosorbent assay. (B) Splenocytes were cultured with $\mathrm{Cll}$ for $40 \mathrm{~h}$, and then cell proliferation was measured by incorporation of [3H]-thymidine. Data are expressed as mean $\pm S D(n=6)$. $* * P<0.01$, and $* * * \mathrm{P}<0.001$ versus vehicle-treated CIA control mice; one-way ANOVA. CIA, collagen-induced arthritis; Cll, collagen type II; KLHTT, Kan-Lu-Hsiao-Tu-Tan. 
A
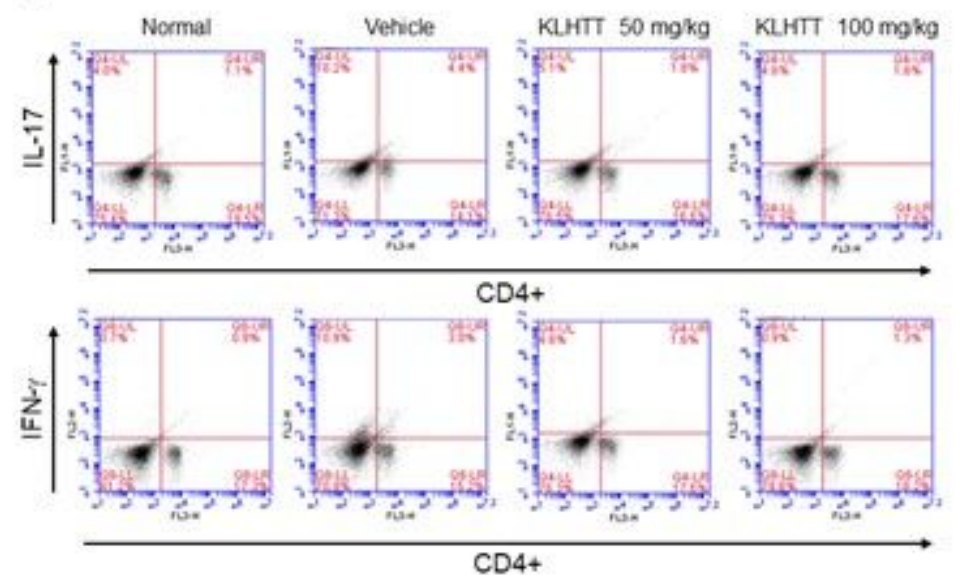

B

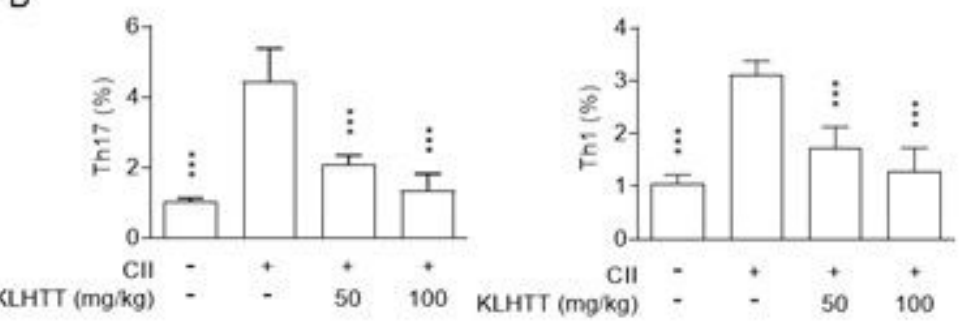

Figure 7

KLHTT reduces the levels of splenic Th1 and Th17 cells in CIA mice. CIA was induced by active immunisation with chicken $\mathrm{Cll}$ in DBA/1 J mice. Drugs were administered orally once a day from day 21 to 42. (A) Splenocytes were cultured with CII for $2 d$, and then stained with PE-conjugated anti-CD4 antibodies followed by FITC-conjugated anti-IL-17A or anti-IFN- $\gamma$ antibodies. Samples were analysed by flow cytometry. (B) Bars display the mean $\pm S D(n=6) . * * * P<0.001$ versus vehicle-treated CIA control mice; one-way ANOVA. CIA, collagen-induced arthritis; Cll, collagen type Il; IL-17, interleukin 17; IFN- $\gamma$, interferon gamma; KLHTT, Kan-Lu-Hsiao-Tu-Tan. 